УДК 616.314.17-008.1:612.015:613.84

DOI 10.11603/mcch.2410-681X.2017.v0.i1.7682

О. Я. Лаврін, В. В. Щерба, І. Я. Криницька

ТЕРНОПІЛЬСЬКИЙ ДЕРЖАВНИЙ МЕДИЧНИЙ УНІВЕРСИТЕТ ІМЕНІ І. Я. ГОРБАЧЕВСЬКОГО

\title{
БІОХІМІЧНІ ЗМІНИ ПАРОДОНТА В ЩУРІВ НА ТЛІ ДІЇ ТЮТЮНОВОГО ДИМУ
}

Вступ. На даний час куріння є одним із значущих чинників ризику розвитку запальних захворювань пародонта. У літературних джерелах багато робіт присвячено дослідженню впливу куріння на стан пародонта. Однак ряд аспектів, зокрема стан вільнорадикального окиснення, залишений без належної уваги.

Мета дослідження - оцінити показники вільнорадикального окиснення у тканинах пародонта щурів на тлі дії тютюнового диму.

Методи дослідження. Експериментальне дослідження виконано на 20 статевозрілих білих иурах-самцях масою 160-180 г. Тварин було поділено на дві групи: контрольну (10 особин) і дослідну (10 особин). Моделювали пасивне тютюнокуріння шляхом поміщення щурів у спеціально сконструйовану камеру, в якій розподіляли тютюновий дим. Тривалість експерименту становила 21 день. Концентрацію 8-ізопростану визначали імунофрерментним методом за допомогою набору "8-isoprostane ELISA" фpipмu "USBiological" (США). Кількісну оцінку вмісту метаболітів нітроген (II) оксиду проводили за визначенням їх суми. Вміст відновленого глутатіону, активність супероксиддисмутази і каталази в гомогенаті тканин пародонта визначали за загальноприйнятими методиками.

Результати й обговорення. Концентрація 8-ізопростану в супернатанті гомогенату пародонта щурів контрольної групи становила $(3,94 \pm 0,18)$ пг/мл. У тварин дослідної групи даний показник достовірно зріс у 2,9 раза. Це свідчить про те, що на тлі дії тютюнового диму в тканинах пародонта розвивається оксидативний стрес, що характеризується збільшенням інтенсивності продукування активних фрорм оксигену. На 22-гу добу експерименту було зафріксовано достовірне зниження активності супероксиддисмутази в гомогенаті тканин пародонта на 40,9% та каталази у 2,4 раза відносно контрольної групи. Відомо, що SH-групи (зокрема, цистеїнових та метіонінових фррагментів білкових молекул) найлегше окиснюються активними фоормами оксигену з утворенням зворотних і незворотних модифрікацій. На 22-гу добу експерименту спостерігали достовірне зниження вмісту відновленого глутатіону в гомогенаті тканин пародонта на 24,4 \% відносно контрольної групи. Вміст метаболітів NO в супернатанті гомогенату пародонта щурів дослідної групи достовірно зменшився у 2,1 раза. Потужними фракторами, що інактивують NO, є вільні радикали, серед яких - супероксидний радикал. Його взаємодія з NO призводить до утворення пероксинітриту, що як сильний окиснювач має високий ступінь цитотоксичності.

Висновки. На тлі дії тютюнового диму в тканинах пародонта щурів достовірно зростає генерація активних фрорм оксигену, знижуються активність супероксиддисмутази, каталази і вміст відновленого глутатіону, що вказує на виражений дисбаланс вільнорадикального гомеостазу. Також на тлі дії тютюнового диму в тканинах пародонта пригнічуються нітроксидергічні процеси за рахунок достовірного зменшення вмісту метаболітів оксиду азоту, що призводить до зниження захисного антибактеріального потенціалу.

КЛЮЧОВІ СЛОВА: пародонт; куріння; оксидативний стрес.

ВСТУП. Сучасна медико-демографрічна ситуація в Україні характеризується тим, що країна вступила в якісно новий етап свого розвитку депопуляцію. Уже 20 років річна чисельність померлих перевищує чисельність народжених. За чотири роки (2006-2010) чисельність населення скоротилася на 1 млн 151 тис. осіб [4]. Це відбувається на тлі прогресуючого поширення тютюнокуріння, а також інших згубних шкідливих (с) О. Я. Лаврін, В. В. Щерба, І. Я. Криницька, 2017. звичок [2]. Кількість курців серед населення щороку зростає: в 90-х роках вона становила 2,6 \% непрацездатних осіб, у 2020 р. прогнозують ії̈ збільшення до 19 \% осіб. У світі налічується близько 1,3 млрд людей, які курять [4, 10], у країнах СНД - приблизно 29 \% дорослого населення, у країнах Європи - до 28 \%. Велику поширеність куріння серед чоловіків відмічають у Латвії, Естонії, Польщі, Молдові, Туреччині, Україні. Найбільше курців серед чоловіків у 
Південній Кореї (68 \%), а серед жінок - у Данії (37\%) [6]. Середньосвітове споживання тютюну становить 1650 цигарок на людину в рік [3]. Важливо відмітити, що населення України становить 0,85 \% від населення Землі, а 1,5\% світової продукції тютюну використовується в Україні. За споживанням цигарок Україна посідає 17-те місце у світі [10].

На даний час куріння $є$ одним із значущих чинників ризику розвитку запальних захворювань пародонта. Патогенез цієї патології тісно пов'язаний 3 порушенням вільнорадикального окиснення в ротовій рідині. Генерація активних форм оксигену і пероксидне окиснення ліпідів зумовлюють стан вільнорадикального окиснення. Вільні радикали викликають оксидативний стрес і можуть пошкоджувати біологічні мембрани [7, 17]. У літературних джерелах багато робіт присвячено дослідженню впливу куріння на стан пародонта. Однак ряд аспектів, зокрема стан вільнорадикального окиснення, залишений без належної уваги. При підвищенні рівня вільних радикалів у ротовій рідині пошкоджуються тканини пародонта, тоді як нестача активних фрорм оксигену сприяє мікробній інвазії. Отже, як збільшення, так і зменшення вмісту вільних радикалів відіграють важливу роль у розвитку захворювань пародонта [5].

Мета дослідження - оцінити показники вільнорадикального окиснення у тканинах пародонта щурів на тлі дії тютюнового диму.

МЕТОДИ ДОСЛІДЖЕННЯ. Експериментальне дослідження виконано на 20 статевозрілих білих щурах-самцях масою 160-180 г. Їх утримували на стандартному раціоні з вільним доступом до води та їжі. Тварин було поділено на дві групи: контрольну (10 особин) і дослідну (10 особин). Моделювали пасивне тютюнокуріння шляхом поміщення щурів у спеціально сконструйовану камеру, в якій розподіляли тютюновий дим. Розрахунок еквівалентної дози нікотину і часу експозиції тварин тютюновим димом проводили на підставі апробованої моделі А. С. Соломіної [12] і розрахунків Л. В. Лізурчик та О. В. Шейди [8]: якщо середньостатистичний курець викурює одну пачку (20 цигарок) на день, то в організм при цьому потрапляє 20 мг нікотину. Тому еквівалентна доза нікотину для щура, від середньої маси людини 70 кг, становитиме 0,043 мг на день. 3 огляду на розрахункові дані, в камеру поміщали по 5 тварин. Задимлення проводили протягом 30 хв шляхом спалювання 2-х цигарок. Піддослідні щури проходили процедуру “пасивного куріння" 2 рази на добу. Таким чином, одна тварина в експерименті отримувала максимум 0,048 мг нікотину, що відповідало добовій дозі для людини. Після закінчення кожного 30-хвилинного сеансу тварин витягали 3 камери і поміщали в стандартну клітку віварію. щурів контрольної групи поміщали в камеру без задимлення 2 рази на добу протягом 30 хв. Тривалість експерименту становила 21 день.

Концентрацію 8-ізопростану в супернатанті гомогенату пародонта визначали імунофрерментним методом за допомогою набору "8-isoprostane ELISA" фрірми "USBiological" (США). Отримані дані виражали в пг/мл.

Кількісну оцінку вмісту метаболітів нітроген (II) оксиду (NO) проводили за визначенням їх суми, яка включає нітрит-іони, які попередньо були присутні у пробі $\left(\mathrm{NO}_{2}^{-}\right)$, і відновлені до нітритів нітрат-іони $\left(\mathrm{NO}_{3}^{-}\right)$[1].

Вміст відновленого глутатіону (SH-груп), активність супероксиддисмутази (СОД) і каталази в гомогенаті тканин пародонта визначали за загальноприйнятими методиками $[9,13,14]$.

Утримували щурів та проводили експерименти відповідно до положень Європейської конвенції про захист хребетних тварин, що використовуються для дослідних та інших наукових цілей [15].

Статистичну обробку цифрових даних здійснювали за допомогою програмного забезпечення Excel ("Microsoft", США) і STATISTICA 6.0 ("Statsoft", США) з використанням непараметричних методів оцінки одержаних даних. Для всіх показників розраховували значення середньої арисрметичної вибірки (М), її дисперсії і помилки середньої (m). Достовірність різниці значень між незалежними кількісними величинами визначали за допомогою критерію Вілкоксона-МаннаУїтні.

РЕЗУЛЬТАТИ Й ОБГОВОРЕННЯ. За СУЧАСними даними, одним 3 найбільш специфічних маркерів, що дозволяють $з$ достатнім ступенем точності, достовірності та відтворюваності результатів дослідження оцінити рівень продукції вільних радикалів в організмі, є 8-ізопростан. Це продукт метаболізму в реакціях пероксидного окиснення арахідонової кислоти, ізомерний простагландину F2 $\alpha$ [19].

Концентрація 8-ізопростану в супернатанті гомогенату пародонта щурів контрольної групи становила $(3,94 \pm 0,18)$ пг/мл (табл.). У тварин дослідної групи даний показник зріс у 2,9 раза і складав $(11,50 \pm 0,39)$ пг/мл. Це свідчить про те, що на тлі дії тютюнового диму в тканинах пародонта розвивається оксидативний стрес, що характеризується збільшенням інтенсивності продукування активних фрорм оксигену. 3 молекулярної точки зору, найбільш несприятливими наслідками при надлишку активних фрорм окси- 
Таблиця - Показники вільнорадикального окиснення у тканинах пародонта щурів

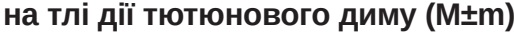

\begin{tabular}{|c|c|c|c|c|}
\hline СОД, ум. од. & $\begin{array}{c}\text { Каталаза, } \\
\text { кат/кг }\end{array}$ & $\begin{array}{c}\text { SH-групи, } \\
\text { моль } \cdot \mathrm{k}^{-1}\end{array}$ & $\begin{array}{l}\mathrm{NO}_{2}^{-}+\mathrm{NO}_{3}^{-} \text {, } \\
\text { мКМоль/Кг }\end{array}$ & 8-ізопростан, пг/мл \\
\hline \multicolumn{5}{|c|}{ Контрольна група (n=10) } \\
\hline $34,89 \pm 0,76$ & $20,67 \pm 1,22$ & $76,18 \pm 1,65$ & $49,48 \pm 4,08$ & $3,94 \pm 0,18$ \\
\hline \multicolumn{5}{|c|}{ Дослідна група (n=10) } \\
\hline $\begin{array}{c}20,62 \pm 0,72 \\
p<0,05\end{array}$ & $\begin{array}{c}8,53 \pm 0,29 \\
p<0,05\end{array}$ & $\begin{array}{c}57,60 \pm 1,47 \\
p<0,05\end{array}$ & $\begin{array}{c}23,05 \pm 2,21 \\
p<0,05\end{array}$ & $\begin{array}{c}11,50 \pm 0,39 \\
p<0,05\end{array}$ \\
\hline
\end{tabular}

Примітка. p - вірогідність відмінностей між контрольною і дослідною групами.

гену є їх взаємодія з амінокислотними залишками в молекулах протеїнів, денатурація функціонально циркулюючих і структурованих у тканинах білків, а також денатурація ДНК [18].

Головною і першорядною перешкодою на шляху утворення активних фрорм оксигену є СОД, що містить у своєму активному центрі мідь, цинк або марганець. На 22-гу добу експерименту було зафріксовано достовірне зниження активності СОД у гомогенаті тканин пародонта на 40,9 \% відносно контрольної групи. Оскільки збільшення в клітині концентрації $\mathrm{H}_{2} \mathrm{O}_{2}$, що утворився в результаті супероксиддисмутазної і ряду інших реакцій, є для клітини не менш небезпечним, ніж збільшення супероксид-аніонів, необхідна його постійна інактивація в реакції, яка каталізується каталазою. Активність каталази в гомогенаті тканин пародонта щурів на тлі дії тютюнового диму зменшилася у 2,4 раза відносно контрольної групи.

Значне зниження активності СОД і каталази можна пояснити використанням ферментів у процесі інактивації високореакційних фрорм оксигену. Слід зазначити, що металовмісні фрерменти також підлягають окиснювальній модифікації з втратою іонів металів, утворенням фрагментів пептидів і подальшим руйнуванням внутрішньоклітинними протеазами [18].

На 22-гу добу експерименту було зафріксовано достовірне зниження вмісту відновленого глутатіону в гомогенаті тканин пародонта на 24,4 \% відносно контрольної групи. Відомо, що SH-групи (зокрема, цистеїнових та метіонінових фррагментів білкових молекул) найлегше окиснюються активними фрормами оксигену з утворенням зворотних і незворотних модифрікацій

\section{СПИСОК ЛІТЕРАТУРИ}

1. Визначення концентрації метаболітів оксиду азоту в сироватці крові / В. В. Козар, М. Я. Кудря, Н. В. Устенко [та ін.] // Лаб. діагностика. - 2010. № 3 (53). - C. 14-16.
[16]. Окиснення SH-груп у білкових молекулах призводить до порушення чи модифрікації їх функції. Зменшення вмісту SH-груп за умови пасивного тютюнокуріння може бути пов'язане як з інтенсифікацією вільнорадикальних процесів, так і з підсиленням катаболізму глутатіону.

Вміст метаболітів NO в супернатанті гомогенату пародонта щурів контрольної групи становив $(49,48 \pm 4,08)$ мкмоль/л. У тварин дослідної групи даний показник зменшився у 2,1 раза і складав $(23,05 \pm 2,21)$ мкмоль/л. Потужними фракторами, що інактивують NO, є вільні радикали, серед яких - супероксидний радикал. Його взаємодія з NO призводить до утворення пероксинітриту, що як сильний окиснювач має високий ступінь цитотоксичності. Підвищення продукції активних орорм оксигену сприяє окисненню тетрагідробіоптерину, що також зумовлює зниження утворення NO. Крім того, пригнічується фрермент диметиларгініндиметиламіногідролаза, в результаті чого підвищується рівень асиметричного диметиларгініну - інгібітора NO-синтази [11].

ВИСНОВКИ. 1. На тлі дії тютюнового диму в тканинах пародонта щурів достовірно зростає генерація активних форм оксигену, знижуються активність супероксиддисмутази, каталази і вміст відновленого глутатіону, що вказує на виражений дисбаланс вільнорадикального гомеостазу.

2. На тлі дії тютюнового диму в тканинах пародонта пригнічуються нітроксидергічні процеси за рахунок достовірного зменшення вмісту метаболітів оксиду азоту, що призводить до зниження захисного антибактеріального потенціалу.

2. Ещенко К. Н. Сердечно-сосудистая система и курение / К. Н. Ещенко, А. В. Жадан, Н. Ф. Шустваль // Ліки України. - 2013. - Вип. 4. - С. 12-17. 
3. Кваша Е. А. Значимость фракторов риска для смертности мужчин (проспективное эпидемиологическое исследование) / Е. А. Кваша // Укр. кардіол. журн. - 2008. - № 2. - С. 83-88.

4. Контроль над тютюном в Україні. Другий Національний звіт. - К. : МОЗ України, ДУ "Український інститут стратегічних досліджень МОЗ України", 2014. - 128 c.

5. Кочиева И. В. Влияние табакокурения на микроциркуляцию в тканях пародонта / И. В. Кочиева, С. Н. Мкртчян, С. К. Хетагуров // Журн. науч. статей “Здоровье и образование в XXI веке". - 2015. - 17, № 1. - С. 57-58.

6. Красовський К. С. Наслідки глобальної тютюнової епідемії/К. С. Красовський // СЕС. Профрілактична медицина. - 2009. - № 4. - С. 72-74.

7. Лечение воспалительных заболеваний пародонта у курящих лиц молодого возраста / Л. П. Герасимова, М. М. Аль-Табиб, М. Ф. Кабирова [и др.] // Фундаментальные исследования. - 2014. - № 7 . С. 463-467.

8. Лизурчик Л. В. Влияние табачного дыма на содержание токсичных элементов в организме крыс / Л. В. Лизурчик, Е. В. Шейда // Вестн. ОГУ. - 2014. № 6 (167). - С. 71-74.

9. Метод определения активности каталазы / М. А. Королюк, Л. И. Иванова, И. Г. Майорова [и др.] // Лаб. дело. - 1988. - № 1. - С. 16-18.

10. Пікас О. Б. Куріння цигарок серед населення та його роль у розвитку захворювань / О. Б. Пікас // Вісн. проблем біології і медицини. - 2016. - 1 (126), вип. 1. - С. 48-52.
11. Роль диссункции эндотелия в патогенезе атеросклероза / Е. Н. Воробьева, Г. И. Шумахер, И. В. Осипова [и др.] // Кардиоваскулярная терапия и профилактика. - 2006. - 5, № 6. - С. 129-136.

12. Соломина А. С. Влияние афобазола на генетическую и репродуктивную токсичность табачного дыма у крыс : дисс. ... канд. биол. наук : 14.03 .06 / Соломина Анна Сергеевна. - М., 2011. - 139 с.

13. Чевари С. Роль супероксидредуктазы в окислительных процессах клетки и метод определения ее в биологическом материале / С. Чевари, И. Чаба, Й. Секей // Лаб. дело. - 1985. - № 11. - С. 678-681.

14. Ellman G. L. Tissue sulfhydryl groups / G. L. Ellman // Arch. Biochem. Biophys. - 1959. - 82. - P. 70-77.

15. European convention for the protection of vertebrate animals used for experimental and other scientific purposes. - Council of Europe. Strasbourg. - 1986. № 123. $-52 \mathrm{p}$.

16. Hansen R. E. Quantifying the global cellular thiol-disulfide status / R. E. Hansen, D. Roth, J. R. Winther // PNAS. - 2009. - 106, № 2. - 422-427.

17. Panjamurthy K. Lipid peroxidation and antioxidant status in patients with periodontitis / K. Panjamurthy, S. Manoharan, C. R. Ramachandran // Cell Mol. Biol. Lett. - 2005. - 10, № 2. - P. 255-264.

18. Shirley R. Oxidative Stress and the Use of Antioxidants in Stroke / R. Shirley, E. N. J. Ord, L. M. Work // Antioxidants. - 2014. - 3. - 472-501.

19. Zhang Z.-J. Systematic review on the association between F2-isoprostanes and cardiovascular disease / Z.-J. Zhang // Ann. Clin. Biochem. -2013. -50. - P. 108114.

5. Kochieva, I.V., Mkrtchian, S.N. \& Khetagurov, S.K. (2015). Vliyanie tabakokureniya na mikrotsirkuliatciyu v tkaniakh paradonta [Influence of tobacco smoking on microcirculation in periodontal tissues]. Zhurnal nauchnykh statei «Zdorove i obrazovanie $v X X I$ veke» - Journal of Scientific articles «Health and education in the XXI century», 17 (1), 57-58 [in Russian]

6. Krasovskyi, K.S. (2009). Naslidky hlobalnoi tiutiunovoi epidemii [The effects of the global tobacco epidemic]. SES. Profilaktychna medytsyna - SES. Preventive Medicine, 4, 72-74 [in Ukrainian].

7. Gerasimova, L.P., Al-Tabib, M.M., Kabirova, M.F., Usmanova, I.N. \& Farkhutdinov, R.R. (2014). Lechenie vospalitelnykh zabolevanii parodonta u kuriashchikh lits molodogo vozrasta [Treatment of inflammatory periodontal diseases in smokers of young age]. Fundamentalnye issledovaniya-Basic Research, 7, 463-467 [in Russian].

8. Lizurchik, L.V. \& Sheida, E.V. (2014). Vliyanie tabachnogo dyma na soderzhanie toksichnykh elementov $v$ organizme krys [Effect of tobacco smoke on the 
content of toxic elements in the body of rats]. Vestnik OGU - Journal of the Orenburg State University, 6 (167), 71-74 [in Russian].

9. Koroliuk, M.A., Ivanova, L.I. \& Mayorova, I.G. (1988). Metod opredeleniya aktivnosti katalazy [Method for the determination of catalase activity]. Laboratornoe delo - Laboratory Work, 1, 16-18 [in Russian].

10. Pikas, O.B. (2016). Kurinnia tsyharok sered naselennia ta yoho rol u rozvytku zakhvoriuvan [Smoking cigarettes among population and its role in development of diseases]. Visnyk problem biolohii i medytsyny - Journal of Medical and Biological Problems, 1, 1(126), 48-52 [in Ukrainian].

11. Vorobeva, E.N., Shumakher, G.I., Osipova, I.V., Khoreva, M.A. \& Vorobev, R.I. (2006). Rol disfunktsii endoteliya $v$ patogeneze ateroskleroza [The role of endothelial dysfunction in the pathogenesis of atherosclerosis]. Kardiovaskuliarnaya terapiya i profilaktika - Cardiovascular Therapy and Prevention, 5 (6), 129-136 [in Russian].

12. Solomina, A.S. (2011). Vliyanie afobazola na geneticheskuyu i reproduktivnuyu toksichnost tabachnogo dyma u krys [The effect of afobazole on the genetic and reproductive toxicity of tobacco smoke in rats]. Candidate's thesis. Moscow: NII farmakologii imeni V.V. Zakusova RAMN [in Russian].
13. Chevari, S., Chaba, I. \& Sekei, I. (1985). Rol superoksidreduktazy $v$ okislitelnykh protsessakh kletki i metod opredeleniya ee $v$ biologicheskom materiale [The role of superoxide reductase in oxidative processes of the cell and the method of its determination in biological material]. Laboratornoe delo - Laboratory Work, 11, 678681 [in Russian].

14. Ellman, G.L. (1959). Tissue sulfhydryl groups. Archives of Biochemistry and Biophysics, 82, 70-77.

15. European convention for the protection of vertebrate animals used for experimental and other scientific purposes. (1986). Council of Europe. Strasbourg, 123, 52.

16. Hansen, R.E., Roth, D. \& Winther, J. R. (2009). Quantifying the global cellular thiol-disulfide status. Proceedings of the National Academy of Sciences, 106, 2, 422-427.

17. Panjamurthy, K., Manoharan, S. \& Ramachandran, C.R. (2005). Lipid peroxidation and antioxidant status in patients with periodontitis. Cellular and Molecular Biology Letters, 10 (2), 255-264.

18. Shirley, R., Ord, E.N.J. \& Work, L.M. (2014). Oxidative Stress and the Use of Antioxidants in Stroke. Antioxidants, 3, 472-501.

19. Zhang, Z.-J. (2013). Systematic review on the association between $\mathrm{F} 2$-isoprostanes and cardiovascular disease. Annals of Clinical Biochemistry, 50, 108-114.-114.

О. Я. Лаврин, В. В. Щерба, И. Я. Криницкая ТЕРНОПОЛЬСКИЙ ГОСУДАРСТВЕННЫЙ МЕДИЦИНСКИЙ УНИВЕРСИТЕТ ИМЕНИ И. Я. ГОРБАЧЕВСКОГО

\section{БИОХИМИЧЕСКИЕ ИЗМЕНЕНИЯ ПАРОДОНТА У КРЫС НА ФОНЕ ДЕЙСТВИЯ ТАБАЧНОГО ДЫМА}

\section{Резюме}

Вступление. В настоящее время курение является одним из значимых фракторов риска развития воспалительных заболеваний пародонта. В литературных источниках много работ посвящено исследованию влияния курения на состояние пародонта. Однако ряд аспектов, в частности состояние свободнорадикального окисления, оставлен без должного внимания.

Цель исследования - исследовать показатели свободнорадикального окисления в тканях пародонта крыс на фроне действия табачного дыма.

Методы исследования. Экспериментальное исследование выполнено на 20 половозрелых белых крысах-самцах массой 160-180 г. Животные были разделены на две группы: контрольную (10 особей) и экспериментальную (10 особей). Моделировали пассивное табакокурение путем помещения крыс в специально сконструированную камеру, в которой распределяли табачный дым. Продолжительность эксперимента составила 21 день. Концентрацию 8-изопростана определяли иммуноферментным методом с помощью набора "8-isoprostane ELISA" формы "USBiological" (США). Количественную оценку содержания метаболитов азота (II) оксида проводили по определению их суммы. Содержание восстановленного глутатиона, активность супероксиддисмутазы и каталазы в гомогенате тканей пародонта определяли по общепринятым методикам.

Результаты и обсуждение. Концентрация 8-изопростана в супернатанте гомогената пародонта крыс контрольной группы составила $(3,94 \pm 0,18)$ пг/мл. У животных экспериментальной группы данный показатель достоверно вырос в 2,9 раза. Это свидетельствует о том, что на фоне действия табачного дыма в тканях пародонта развивается окислительный стресс, характеризующийся увеличением интенсивности продуцирования активных форм кислорода. На 22-е сутки эксперимента было зафиксировано достоверное снижение активности супероксиддисмутазы в гомогенате тканей пародонта на 40,9 \% и каталазы в 2,4 раза относительно контрольной группы. Известно, что SH-группы (в частности, цистеиновых и метиониновых фррагментов белковых молекул) легче всего окисляются активными фрор- 
мами кислорода с образованием обратимых и необратимых модификаций. На 22-е сутки эксперимента наблюдали достоверное снижение содержания восстановленного глутатиона в гомогенате тканей пародонта на 24,4 \% относительно контрольной группы. Содержание метаболитов NO в супернатанте гомогената пародонта крыс экспериментальной группы достоверно уменьшилось в 2,1 раза. Мощными фракторами, которые инактивируют NO, выступают свободные радикалы, среди которых - супероксидный радикал. Его взаимодействие с NO приводит к образованию пероксинитрита, который как сильный окислитель имеет высокую степень цитотоксичности.

Выводы. На фроне действия табачного дыма в тканях парадонта крыс достоверно возрастает генерация активных форм кислорода, снижаются активность супероксиддисмутазы, каталазы и содержание восстановленного глутатиона, что указывает на выраженный дисбаланс свободнорадикального гомеостаза. Также на фроне действия табачного дыма в тканях пародонта угнетаются нитроксидергические процессы за счет достоверного уменьшения содержания метаболитов оксида азота, что приводит к снижению защитного антибактериального потенциала.

КЛЮЧЕВЫЕ СЛОВА: пародонт; курение; окислительный стресс.

O. Ya. Lavrin, V. V. Shcherba, I. Ya. Krynytska

I. HORBACHEVSKY TERNOPIL STATE MEDICAL UNIVERSITY

\section{BIOCHEMICAL CHANGES IN RATS’ PERIODONT ON THE BACKGROUND OF SMOKING}

\section{Summary}

Introduction. In our days, smoking is one of the most important risk factors for inflammatory diseases. There is a lot of scientific data, devoted to research the effects of smoking on periodontal status. However, some aspects such as the status of free-radical oxidation, is left without proper attention.

The aim of the study - to investigate experimentally the indices of free radical oxidation in periodontal tissues on the background of smoking.

Methods of the research. Experimental studies were performed on 20 adult male albino rats weighing $160-180 \mathrm{~g}$. Animals were divided into 2 groups: control (10 animals) and experimental (10 animals). Modeling of passive smoking was carried out by placing rats in a specially designed chamber in which tobacco smoke was distributed. The duration of the experiment was 21 days. The concentration of 8-isoprostane was determined by ELISA method using a set of "8-isoprostane ELISA" company "USBiological" (USA). Quantitative assessment of the content of metabolites of nitrogen (II) oxide was carried out by determining their amount. The content of reduced glutathione, superoxide dismutase and catalase activity in periodontal tissue homogenate were determined by conventional methods.

Results and Discussion. Concentration of 8-isoprostane in supernatant of periodontal homogenate in rats of control group was $(3.94 \pm 0.18) \mathrm{pg} / \mathrm{ml}$. In experimental animals this index was significantly increased in 2.9 times. This indicates that despite the action of tobacco smoke in periodontal tissues oxidative stress develops, characterized by the increasing intensity of the production of reactive oxygen species. On 22 day of the experiment, we have observed a significant decrease in superoxide dismutase activity in periodontal tissue homogenate by $40.9 \%$ and catalase activity in 2.4 times compared to the control group. It is known that SH-groups (such as cysteine and methionine fragments of protein molecules) are most easily oxidized by reactive oxygen species to form a reversible and irreversible modifications. On 22 day of the experiment, we have observed a significant decrease in glutathione content in periodontal tissue homogenate by $24.4 \%$ compared to the control group. The content of NO metabolites in supernatant of periodontal homogenate in rats of experimental group was significantly decreased in 2.1 times. The powerful factors that inactivate NO, are free radicals, among them - superoxide radical. Its interaction with NO leads to formation of peroxynitrite that as a strong oxidant has high degree of cytotoxicity.

Conclusions. In rats on the background of tobacco smoke in periodontal tissues significantly increases the generation of reactive oxygen species, reduces superoxide dismutase, and catalase activity and glutathione content, indicating a marked imbalance of free radical homeostasis. On the background of tobacco smoke in periodontal tissues occurs inhibition of nitroxydergic processes through significant reduction of nitric oxide metabolites content, which reduces the protective antibacterial potential.

KEY WORDS: periodont; smoking; oxidative stress.

Отримано 16.02.17

Адреса для листування: О. Я. Лаврін, Тернопільський державний медичний університет імені І. Я. Горбачевського, м. Волі, 1, Тернопіль, 46001, Україна, e-mail: Lavrin.ox@mail.ru. 